\title{
Frekuensi dan Determinan Kontrasepsi Pria di Indonesia
}

\section{Ahmad*}

\begin{abstract}
Abstrak
Pertumbuhan penduduk Indonesia terlihat tinggi (1,25\%) dengan pertambahan sekitar 7,3 juta penduduk setiap tahun . Sejak tahun 1980,program keluarga berencana berkontribusi terhadap penurunan angka fertilitas dari 5,61 menjadi 2,6 pada tahun 2002. Kontribusi pria menggunakan kontrasepsi berhubungan dengan banyak faktor antara lain meliputi pengetahuan, sikap, praktek, keterbatasan informasi aksesibilitas fasilitas pelayanan kontrasepsi pria, keterbatasan jenis kontrasepsi, dan persepsi masyarakat yang kurang menguntungkan. Penelitian ini bertujuan untuk mengetahui berbagai faktor yang berhubungan dengan penggunaan kontrasepsi pria di Indonesia. Penelitian ini menggunakan sumber data sekunder Survei Demografi Kesehatan Indonesia ( SDKI ) tahun 2002-2003. Disain penelitian yang digunakan adalah Cross Sectional dengan metode analisis Regresi Logistik. Hasil penelitian menunjukkan proporsi penggunaan kontrasepsi pria didasari pada Current User dan Ever User 2002/ 2003 masih rendah (7,7\%). Sebaran metode kontrasepsi pria pada responden ( 504, 3,1\%) dan senggama terputus (593, 3,6\%). Variabel usia, pendidikan, tempat tinggal kemandirian mendapatkan kontrasepsi, pengetahuan berhubungan secara bermakna dengan penggunaan kontrasepsi pria. Variabel pendidikan berinteraksi dengan kemandirian. Variabel yang berhubungan sangat erat dengan penggunaan kontrasepsi pria adalah pengetahuan (nilai- $p=0,000 ; O R=28,211 ; 95 \% \mathrm{Cl} ; 18,936-42,027$.
\end{abstract}

Kata kunci : Kontrasepsi pria, pengetahuan.

\section{Abstract}

Population growth in Indonesia is high (1.25\%), with additional 7,3 million people each year. Since 1980, family planning gives contribution to the reduction of fertility rate from 5.61 to 2.6 in year 2002. Male contribution by using contraceptive methods is related to many factors such as knowledge, attitude, practice, information limitation, contraception availability and community perception on male contraceptive. This study is aimed to gain information about factors related to the use of male contraceptive methods in Indonesia. This study uses secondary data from SDKI 2002-2003. Study design used is cross sectional with statistical logistic regression analysis. The study results show that proportion of male using contraceptive method is low, only about $7.7 \%$. The methods used include vasectomy $0.5 \%$, condom $2.4 \%$, abstinence $3.1 \%$, and withdrawal $3.6 \%$. Factors related to male contraceptive use are age, education level, residential areas, autonomy in family planning service, knowledge about family planning and male contraceptive, and interaction variable is education*autonomy in family planning service. The most dominant factor to male contraceptive is knowledge about family planning and male contraceptive at $p$-value $0.000, \mathrm{OR}=28.211,95 \% \mathrm{Cl}=18.9-42.0$.

Key words : Male contraceptive, knowledge. 
Indonesia merupakan negara dengan jumlah penduduk terbesar keempat di dunia setelah Republik Rakyat China, India dan Amerika Serikat. ${ }^{1}$ Pada periode 2000 2002, penduduk Indonesia meningkat 1,25\% atau seki$\operatorname{tar} 7,3$ juta jiwa setiap tahun. Setelah lebih tiga dasa warsa pelaksanaan Program KB Nasional, banyak hasil yang telah dicapai, antara lain angka pemakaian kontrasepsi yang makin meningkat, seperti terlihat pada proporsi peserta KB untuk semua cara/metode $(60,3 \%)$ yang meliputi suntikan $(27,8 \%)$, pil $(13,2 \%)$, IUD $(6,2 \%)$, implant/susuk $(4,3 \%)$, sterilisasi wanita $(3,7 \%)$, kondom $(0,9 \%)$, sterilisasi pria $(0,4 \%)$, pantang berkala $(1,6 \%)$. Jelas terlihat bahwa penurunan angka fertilitas lebih didominasi partisipasi aktif para istri $(55,2 \%)$, sementara partisipasi pria masih sangat rendah. Pada periode 1991$1994(3,5 \%)$ dan pada periode 1997 meningkat menjadi 5,9\% dan pada periode 2002 kembali turun (4,4\%). Angka ini merupakan yang terendah dibandingkan dengan berbagai negara di Asia antara lain meliputi Malaysia (16,8\%), Bangladesh (13,9\%), dan Iran $(13 \%) .^{2}$

Partisipasi pria pengguna kontrasepsi yang rendah tersebut dapat dilihat dari berbagai aspek. Dilihat dari aspek pria meliputi faktor pengetahuan, sikap, praktek serta kebutuhan yang diinginkan, serta keterbatasan informasi dan aksesibilitas terhadap pelayanan kontrasepsi pria, keterbatasan jenis kontrasepsi, persepsi masyarakat yang kurang menguntungkan. Ada tiga faktor utama yang membuat partisipasi pria dalam $\mathrm{KB}$ rendah, antara lain meliputi perbedaan peran jender antara suami dan istri, metode kontrasepsi yang terbatas serta pengetahuan pria tentang kontrasepsi yang kurang. ${ }^{3}$ Dua faktor yang sangat berpengaruh pada partisipasi pria yang rendah dalam program KB adalah peran suami yang lebih dominan dan kesiapan istri yang lebih tinggi untuk menerima program KB. Pembahasan tentang KB, selalu lebih terfokus pada istri, sementara kaum pria seakan tidak berhubungan dengan perencanaan kehamilan dan kelahiran. Hal tersebut mendukung kuat pendapat yang salah bahwa kontrasepsi adalah urusan perempuan. ${ }^{3}$

Berdasarkan aspek aksesibilitas, pelayanan kontrasepsi pria yang saat ini tersedia adalah vasektomi, kondom, pantang berkala dan senggama terputus. Setiap metode kontrasepsi tersebut mempunyai keterbatasan, metode vasektomi kurang berkembang yang terlihat dari periode data SDKI, yang memperlihatkan metode ini bahkan menurun tajam. Masyarakat memandang vasektomi berhubungan dengan indikasi medis bukan cara pengaturan kelahiran. Minat sterilisasi pria sangat kecil, meskipun kebanyakan laki-laki setuju menggunakannya sebagai metode pengendalian kehamilan. ${ }^{4}$ Tujuan penelitian ini adalah mengetahui gambaran penggunaan kontrasepsi pria di Indonesia serta hubungan antara usia, tingkat pendidikan, pekerjaan, area, dan pengetahuan tentang
KB dengan penggunaan kontrasepsi pria. Juga untuk mengetahui hubungan antara persetujuan istri, kemandirian dan jumlah anak dengan penggunaan kontrasepsi pria.

\section{Metode}

Penelitian ini menggunakan data sekunder SDKI 2002/2003 dengan desain studi cross sectional. Populasi penelitian adalah pria berstatus kawin dengan istri usia reproduksi yaitu 15-49 tahun di Indonesia. Sampel penelitian ini adalah seluruh responden pria berstatus kawin dengan istri usia reproduksi (15-49 tahun) pada saat survei SDKI 2002/2003 dilaksanakan menggunakan kontrasepsi atau pernah menggunakan kontrasepsi yang tercatat secara lengkap dan besar sampel adalah 16.366 orang. Analisis ukuran epidemiologi yang digunakan meliputi ukuran frekuensi prevalensi, ukuran asosiasi rasio odds. Tahapan analisis yang dilakukan meliputi analisis univariat, analisis bivariat dan analisis multivariat. Analisis univariat digunakan untuk menilai fenomena frekuensi dan distribusi, analisis bivariat dengan uji statistik chi square digunakan untuk menyeleksi kandidat variabel model multivariat dan analisis multivariat digunakan untuk menilai pengaruh faktor yang berpengaruh setelah mengendalikan faktor lain.

\section{Hasil}

Penggunaan kontrasepsi pria berdasarkan status penggunaan saat survei (current user) adalah 4,4\% dan status penggunaan kontrasepsi pria sebelumnya (ever user) adalah 3,3\%. Distribusi metode responden berdasarkan kontrasepsi pria meliputi vasektomi $(81 ; 0,5 \%)$ kondom $(386 ; 2,4 \%)$ pantang berkala $(504 ; 3,1 \%)$ dan senggama terputus $(593 ; 3,6 \%)$. Rata-rata usia responden adalah 38 tahun dengan usia termuda 19 tahun dan tertua 54 tahun serta median usia 37 tahun dan sebagian besar responden berusia di bawah 37 tahun $(52,8 \%)$. Latar belakang pendidikan responden sebagian besar berpendidikan rendah sebanyak 7.949 orang $(48,6 \%)$, berpendidikan menengah sebanyak 7.402 orang $(45,2 \%)$, dan pendidikan tinggi 1.015 orang $(6,2 \%)$. Sekitar $17,7 \%$ responden tidak bekerja. Sebagian besar responden mengetahui KB dan kontrasepsi pria $(66,4 \%)$ dan sebagian besar istri tidak setuju suaminya memakai kontrasepsi (96,7\%). Kemandirian yang ditentukan pada status bayar sendiri $(42,8 \%)$. Sebagian besar responden pengguna kontrasepsi $(63,8 \%)$ mempunyai anak kurang dari 2 orang.

\section{Analisis Multivariat \\ Seleksi Kandidat Model}

Seleksi kandidat variabel independen multi variat dilakukan dengan metode uji statistik chi-square dengan 
Tabel 1. Hasil Analisis Bivariat

\begin{tabular}{lll}
\hline Variabel & Katagori & Nilai p \\
\hline Usia & $<=37$ tahun & 0,030 \\
Pendidikan & $\begin{array}{l}\text { Tinggi } \\
\text { Menengah }\end{array}$ & 0,000 \\
& $\begin{array}{l}\text { Rendah } \\
\text { Bekerja }\end{array}$ & \\
Pekerjaan & $\begin{array}{l}\text { Tidak Bekerja } \\
\text { Tahu }\end{array}$ & 0,333 \\
Pengetahuan KB & $\begin{array}{l}\text { Tidak Tahu } \\
\text { Setuju }\end{array}$ & 0,000 \\
Persetujuan Istri & $\begin{array}{l}\text { Tidak Setuju } \\
\text { Mandiri }\end{array}$ & 0,829 \\
Kemandirian & $\begin{array}{l}\text { Tidak Mandiri } \\
\text { Kota } \\
\text { Tempat Tinggal }\end{array}$ & 0,000 \\
Jumlah Anak & $\begin{array}{l}\text { Desa } \\
0-2 \text { anak } \\
>2 \text { anak }\end{array}$ & 0,000 \\
& & 0,122 \\
\end{tabular}

kriteria nilai $p \leq 0,25$. Hasil analisis bivariat, variabel independen yang memenuhi kriteria kandidat model multivariat adalah usia, pendidikan, pengetahuan KB, kemandirian, tempat tinggal dan jumlah anak (Lihat Tabel $1)$.

Analisis multivariat tahap I, variabel yang berhubungan bermakna dengan penggunaan alat kontrasepsi adalah pendidikan, tempat tinggal, kemandirian dan pengetahuan (Lihat Tabel 2).

Pada model akhir terlihat bahwa variabel usia, pendidikan, tempat tinggal, kemandirian, pengetahuan KB dan interaksi pendidikan*kemandirian secara signifikan dominan berhubungan dengan penggunaan kontrasepsi pria. Variabel yang paling erat berhubungan dengan penggunaan kontrasepsi pria adalah tingkat pengetahuan (nilai-p $=0,00 ;$ OR $=28,2 ; 95 \%$ CI OR $=18,9-42,0)$ (Lihat Tabel 3).

\section{Pembahasan \\ Keterbatasan Penelitian}

Penelitian ini menggunakan desain penelitian cross sectional (potong lintang), yang mengukur variabel dependen dan independen pada waktu bersamaan. Oleh sebab itu, kelemahan penelitian ini adalah tidak dapat menggambarkan sekuensi waktu antara variabel independen dan dependen. ${ }^{5}$ Sumber data yang digunakan adalah data sekunder SDKI 2002/2003 dengan jumlah observasi 16.366 responden. Data kerja diperoleh dari penggabungan dua file data yaitu data kuesioner pria dan data kuesioner wanita untuk mengambil variabel-variabel penelitian yang dibutuhkan. Reliabilitas dari data ini cukup baik, hal ini diketahui dengan instrumen pengumpulan data yang digunakan konsisten, adanya pedoman pengisian kuesioner, dan instrumen telah melalui uji coba, serta adanya tenaga supervisi terhadap petugas la- pangan pengumpul data. Meskipun demikian, penggunaan data sekunder mempunyai kelemahan antara lain penentuan variabel-variabel penelitian harus disesuaikan dengan butir-butir pertanyaan yang ada, sehingga generalisasi hasil penelitian menjadi terbatas.

\section{Penggunaan Kontrasepsi Pria}

Pada penelitian ini, penggunaan kontrasepsi pria ditentukan berdasarkan pada penggunaan kontrasepsi saat survei dan sebelumnya (current dan ever user). Penelitian menemukan bahwa penggunaan kontrasepsi pria tergolong rendah yaitu 1.266 orang $(7,7 \%)$, dengan rincian vasektomi 81 orang $(0,5 \%)$, kondom 386 orang $(2,4 \%)$, pantang berkala 504 orang $(3,1 \%)$, dan senggama terputus 593 orang $(3,6 \%)$. Menurut WHO (1990) penggunaan kontrasepsi pria yang rendah disebabkan oleh keterbatasan metode KB yang dapat dipilih oleh pria. Cara pengaturan kelahiran bagi pria sampai saat ini belum ada yang lengkap dan ideal. Pantang berkala sulit dilaksanakan karena kendala ketaatan. Angka kegagalan senggama terputus cukup tinggi, kondom banyak tidak disukai karena tidak nyaman dan vasektomi mempunyai kendala akseptabilitas dan reversibilitas. ${ }^{6}$

\section{Faktor-faktor yang Berhubungan}

Penelitian ini menemukan bahwa sebagian besar responden yang menggunakan kontrasepsi pria berusia lebih dari 37 tahun $(7,3 \%)$. Hasil penelitian ini memperlihatkan bahwa ada hubungan yang signifikan antara penggunaan kontrasepsi dengan usia responden $\mathrm{OR}=1,14$; $95 \%$ OR $=1,012-1,275$. Alat kontrasepsi digunakan pada masa reproduksi sebagai upaya penjarangan atau pembatasan kelahiran. ${ }^{4}$ Pada penelitian sebelumnya diketahui bahwa usia terbaik untuk menjarangkan kelahiran anak pada wanita adalah 20-35 tahun. ${ }^{7}$ Keinginan suami untuk menggunakan kontrasepsi berdasarkan usia dan status perkawinan memperlihatkan bahwa usia dewasa dan status kawin berpengaruh terhadap penerimaan kontrasepsi. Penelitian yang dilakukan di Jawa Barat dan Sumatera Selatan menunjukkan bahwa rata-rata usia suami yang menggunakan kontrasepsi di Jawa Barat adalah 39 tahun, sementara di Sumatera Selatan adalah 38 tahun. 8

Pendidikan diketahui merupakan salah satu faktor determinan yang berpengaruh terhadap persepsi penerimaan berbagai gagasan/teknologi baru. Pada umumnya, kedudukan suami sebagai kepala keluarga menempatkan suami pada posisi sentral dalam sistem pengambilan keputusan keluarga. Tingkat pendidikan suami yang semakin tinggi semakin besar peluang mempertimbangkan bahwa aset keluarga bukan hanya anak, tetapi lebih dari itu adalah kewajiban-kewajiban yang harus dipenuhi orang tua terhadap masa depan anak-anaknya. Pendidikan suami yang semakin tinggi terbukti menem- 
Tabel 2. Hasil Analisis Multivariat Tahap I

\begin{tabular}{|c|c|c|c|c|c|}
\hline Variabel & Katagori & B & SE & $\operatorname{Exp}(\beta)$ & P-value \\
\hline Jumlah Anak & $\begin{array}{l}0-2 \text { anak } \\
>2 \text { anak }\end{array}$ & 0.064 & 0.065 & 0.938 & 0.322 \\
\hline Usia & $\begin{array}{l}<=37 \text { tahun } \\
>37 \text { tahun }\end{array}$ & 0.108 & 0.063 & 1.114 & 0.089 \\
\hline Pendidikan & $\begin{array}{l}\text { Tinggi } \\
\text { Menengah }\end{array}$ & $\begin{array}{l}1.175 \\
0.627\end{array}$ & $\begin{array}{l}0.107 \\
0.099\end{array}$ & $\begin{array}{l}3.237 \\
1.871\end{array}$ & 0.000 \\
\hline Tempat Tinggal & $\begin{array}{l}\text { Desa } \\
\text { Kota }\end{array}$ & 0.334 & 0.064 & 1.396 & 0.000 \\
\hline Kemandirian & $\begin{array}{l}\text { Mandiri } \\
\text { Tidak Mandiri }\end{array}$ & 1.127 & 0.063 & 3.086 & 0.000 \\
\hline Pengetahuan KB & $\begin{array}{l}\text { Tahu } \\
\text { Tidak Tahu }\end{array}$ & 3.335 & 0.203 & 28.086 & 0.000 \\
\hline
\end{tabular}

Tabel 3. Model Multivariat Akhir

\begin{tabular}{|c|c|c|c|c|c|}
\hline Variabel & B & SE & $\operatorname{Exp}(\beta)$ & P-value & 95\% CI \\
\hline Usia & 0,122 & 0,062 & 1,130 & 0,047 & $1,001-1,275$ \\
\hline Pendidikan & & & & 0,000 & \\
\hline Tinggi (1) & 1,250 & 0,133 & 3,492 & & $2,691-4,531$ \\
\hline Menengah (2) & 0,808 & 0,126 & 2,244 & & $1,752-2,874$ \\
\hline Tempat Tinggal & 0,333 & 0,064 & 1,396 & 0,000 & $1,232-1,581$ \\
\hline Kemandirian & 1,438 & 0,187 & 4,214 & 0,000 & $2,921-6,078$ \\
\hline Pengetahuan KB & 3,340 & 0,203 & 28,211 & 0,000 & $18,936-42,027$ \\
\hline Interaksi Pendidikan*Kemandirian & & & & 0,025 & \\
\hline Tk. Pendidikan*Kemandirian (1) & 0,164 & 0,220 & 0,849 & & $0,552-1,306$ \\
\hline Tk. Pendidikan*Kemandirian (2) & 0,455 & 0,205 & 0,634 & & $0,425-0,947$ \\
\hline Constanta & 0,388 & 0,118 & 1,473 & 0,001 & \\
\hline
\end{tabular}

patkan kualitas anak sebagai pilihan penting keluarga. ${ }^{9}$ Sesuai dengan penelitian sebelumnya, penelitian ini menemukan hubungan yang bermakna antara tingkat pendidikan responden dengan penggunaan kontrasepsi ( $p$ value $=0,000$ ) .

Partisipasi pria dalam KB dan kesehatan reproduksi juga berhubungan dengan upaya sosialisasi metoda kontrasepsi pria yang rendah. Pro-kontra pada proses Komunikasi Informasi dan Eduksi (KIE) alat kontrasepsi pria mengindikasikan bahwa upaya promosi kontrasepsi pria yang belum maksimal. ${ }^{10}$ Pada penelitian ini, pria yang tidak tahu KB dan kontrasepsi masih rendah $(0,5 \%)$. Hasil analisis multivariat diketahui variabel pengetahuan berhubungan signifikan dengan penggunaan kontrasepsi pria $(\mathrm{p}=0,000 ; \mathrm{OR}=28,211 ; 95 \% \mathrm{CI}$ $=18,936-42,027)$. Dengan nilai OR sebesar 28,211 itu berarti bahwa responden yang tahu tentang KB dan kontrasepsi berpeluang 28,2 kali untuk menggunakan kontrasepsi.

Kemandirian, kesanggupan klien membayar pelayanan ataupun alat kontrasepsi yang digunakan ditentukan berdasarkan kesediaan responden membayar alat/meto- de kontrasepsi yang digunakan. Analisa univariat diketahui bahwa sebagian besar responden tidak mandiri $(57,2 \%)$. Pada model akhir diketahui variabel kemandirian berhubungan dominan erat dengan penggunaan kontrasepsi pria $(\mathrm{p}=0,000 ; \mathrm{OR}=4,214 ; 95 \% \mathrm{CI}=2,921$ $6,078)$. Perlu direkomendasikan bahwa program KB mengusahakan kemudahan istri dan suami untuk mendapatkan pelayanan KB. ${ }^{11}$

Pada penelitian ini ditemukan bahwa lebih dari $60 \%$ pengguna alat kontrasepsi pria tinggal di perkotaan membuktikan bahwa perbedaan daerah tempat tinggal merupakan faktor penentu penggunaan kontrasepsi. Secara umum telah terbukti bahwa di negara maju dan negara berkembang, prevalensi penggunaan kontrasepsi di daerah perkotaan lebih tinggi daripada di daerah pedesaan. Penggunaan alat kontrasepsi pria yang tinggi di perkotaan terutama disebabkan oleh kemudahan akses fasilitas pelayanan kontrasepsi dan ketersediaan alat kontrasepsi. ${ }^{12}$ Temuan penelitian ini sesuai dengan peneliti sebelumnya bahwa proporsi penggunaan kontrasepsi pria di perkotaan $(10,5 \%)$, lebih besar daripada di pedesaan $(5,7 \%)$. Area tempat tinggal berhubungan bermakna 
dengan penggunaan alat kontrasepsi pada pria $(\mathrm{OR}=$ 1,946; dan 95\% CI OR = 1,7-2,2). Pria yang tinggal di perkotaan berpeluang menggunakan kontrasepsi 1,95 kali lebih besar daripada yang tinggal di pedesaan.

Jumlah anak yang masih hidup juga merupakan faktor yang mempengaruhi penggunaan kontrasepsi oral pada pria. Penelitian di Jawa Timur menunjukkan bahwa jumlah anak yang masih hidup merupakan faktor yang sangat penting dalam penentuan pemakaian alat kontrasepsi pria. Ada hubungan yang bermakna antara jumlah anak dengan partisipasi pria dalam menggunakan vasektomi. Namun, pada penelitian ini tidak ditemukan hubungan yang bermakna antara jumlah anak dengan penggunaan kontrasepsi pada pria $(\mathrm{p}$-value $=0,122) .13$

\section{Kesimpulan}

Pada penelitian ini ditemukan prevalensi menggunakan kontrasepsi pada pria adalah $(7,7 \%)$. Penggunaan kontrasepsi pria berdasarkan status penggunaan saat survei (current user) adalah $4,4 \%$ dan status penggunaan kontrasepsi pria sebelumnya (ever user) adalah 3,3\%. Distribusi metode responden berdasarkan kontrasepsi pria meliputi vasektomi $(81 ; 0,5 \%)$ kondom (386; $2,4 \%)$ pantang berkala $(504 ; 3,1 \%)$ dan senggama terputus $(593 ; 3,6 \%)$. Variabel yang berhubungan dengan penggunaan kontrasepsi pria meliputi umur, pendidikan, pengetahuan $\mathrm{KB}$, kemandirian dan tempat tinggal.

\section{Saran}

Peluang untuk meningkatkan keterlibatan pria pada penggunaan kontrasepsi dan penurunan angka fertilitas masih sangat besar terbukti dengan prevalensinya yang relatif sangat kecil. Untuk itu upaya meningkatkan keterlibatan pria pada pengendalian kesuburan masih perlu untuk terus digalakkan melalui upaya pemasaran sosial, menyediakan kontrasepsi efektif dan menyediakan fasilitas pelayanan kontrasepsi pria secara lebih luas, baik di daerah perkotaan maupun daerah pedesaan.

\section{Daftar Pustaka}

1. Population Reference Bureau. Demografic data and estimates for the countries and regions of the world. New York; 2000.

2. Badan Koordinasi Keluarga Berencana. Partisipasi pria/suami dalam keluarga berencana dan kesehatan reproduksi. Jakarta: BKKBN; 2002.

3. Pangkahila. Perspektif keikutsertaan pria ber-KB sebagai evaluasi pelaksnaan KB nasional. Jakarta: Orasi dalam Konsolidasi Pejabat Esselon II dan III BKKBN; 2000.

4. Suprihastuti D. Pengambilan keputusan penggunaan alat kontrasepsi pria di Indonesia (analisis lanjut hasil SDKI 1997). DI Yogyakarta; 2000.

5. Pratikna, Ahmad Watik. Dasar-dasar metodologi penelitian kedokteran dan kesehatan. Cetakan Kedua. Jakarta: PT. Raja Grafindo Persada; 1993.

6. Asih, Leli \& Hadriah Oesman. Studi peran pria dalam penggunaan kontrasepsi di Jawa Barat dan Sumatra Selatan. Jakarta: BKKBN; 2002.

7. Hartanto, Hanafi. Keluarga berencana dan kontrasepsi. Jakarta: Pustaka Sinar Harapan; 1998.

8. Badan Koordinasi Keluarga Berencana. Pedoman pengembangan kelompok sebaya (peer group) sebagai upaya peningkatan partisipasi pria dalam keluarga berencana dan kesehatan reproduksi. Jakarta: BKKBN; 2001.

9. Badan Koordinasi Keluarga Berencana. Studi gender peran pria dalam penggunaan kontrasepsi di DIY. Jakarta: Fakultas Kedokteran Muhammadiyah-PIBIO BKKBN; 1999.

10. Badan Koordinasi Keluarga Berencana. Panduan sosialisaasi peningkatan program KB dan kesehatan reproduksi. Jakarta: BKKBN dan ADB; 2006.

11. Westoff, Charles E. Permintaan alat KB di negara berkembang tahun 2000. Jakarta; 2000.

12. Bertrand, Jane T. Audience researche for improving family planning communication program. Community and family study Centre University or Chicago; 1980.

13. Soeradji. Analisis kebutuhan dan putus pemakaian alat kontrasepsi. Jakarta: BKKBN-BPS LDFEUI; 1981. 